\title{
Tetranucleotide usage in mycobacteriophage genomes: alignment-free methods to cluster phage and infer evolutionary relationships
}

\author{
Benjamin Siranosian ${ }^{1,2^{*}}$, Emma Herold $^{2}$, Edward Williams² ${ }^{2}$ Chen $\mathrm{Ye}^{2}$, Christopher de Graffenried ${ }^{3}$ \\ From Tenth International Society for Computational Biology (ISCB) Student Council Symposium 2014 \\ Boston, MA, USA. 11 July 2014
}

\section{Background}

The genomic sequences of phages isolated on mycobacterial hosts are diverse, mosaic and often share little nucleotide similarity. However, about 30 unique types have been isolated, allowing most phage to be grouped into clusters and further into subclusters [1]. Many tools for the analysis of mycobacteriophage genomes depend on sequence alignment or knowledge of gene content. These methods are computationally expensive, can require significant manual input (for example, gene annotation) and can be ineffective for significantly diverged sequences [2]. We evaluated tetranucleotide usage in mycobacteriophages as an alternative to alignment-based methods for genome analysis.

\section{Description}

We computed tetranucleotide usage deviation, the ratio of observed counts of 4-mers in a genome to the expected count under a null model [3]. Tetranucleotide usage deviation is comparable for members of the same phage subcluster and distinct between subclusters. Neighbor joining phylogenetic trees were constructed on pairwise Euclidean distances between all genomes in the mycobacteriophage database. In almost every case, phage were placed in a monophyletic clade with members of the same subcluster. With few exceptions, trees computed from tetranucleotide usage deviation accurately reconstruct trees based on gene content for a subset of the mycobacteriophage population (Figure 1). We also evaluated the possibility of assigning clusters to unknown phage based on tetranucleotide usage deviation. Under a

\footnotetext{
* Correspondence: Benjamin_siranosian@brown.edu

${ }^{1}$ Center for Computational Molecular Biology, Brown University, Providence, RI, USA

Full list of author information is available at the end of the article
}

simple nearest neighbor classifier, cluster assignments were recovered at a frequency greater than $98 \%$. In addition, we looked for evidence of horizontal gene transfer by using tetranucleotide difference index, a measure of the deviation in tetranucleotide usage from the genomic mean in a sliding window across the genome [3]. Tetranucleotide difference index plots showed a strong spike at the end of cluster L mycobacteriophages, which could indicate horizontal gene transfer in the region.

\section{Conclusions}

Genome analysis based on tetranucleotide usage shows promise for evaluating host-parasite coevolution and gene exchange within the mycobacteriophage population. These methods are computationally inexpensive and independent of gene annotation, making them optimal candidates for further research aimed at clustering phage and determining evolutionary relationships. Code for genome analysis and data used in this project are freely available at https://github.com/bsiranosian/ tango_final.

\footnotetext{
Authors' details

${ }^{1}$ Center for Computational Molecular Biology, Brown University, Providence, RI, USA. ${ }^{2}$ Division of Biology and Medicine, Brown University, Providence, RI, USA. ${ }^{3}$ Department of Molecular Microbiology and Immunology, Brown University, Providence, RI, USA.

Published: 28 January 2015

\section{References \\ 1. Hatfull GF: Mycobacteriophages: Windows into Tuberculosis. PLoS Pathog 2014, 10:e1003953. \\ 2. Vinga S, Almeida J: Alignment-free sequence comparison-a review. Bioinformatics 2003, 19:513-523. \\ 3. Pride DT, Wassenaar TM, Ghose C, Blaser MJ: Evidence of host-virus co- evolution in tetranucleotide usage patterns of bacteriophages and eukaryotic viruses. BMC Genomics 2006, 7:8}




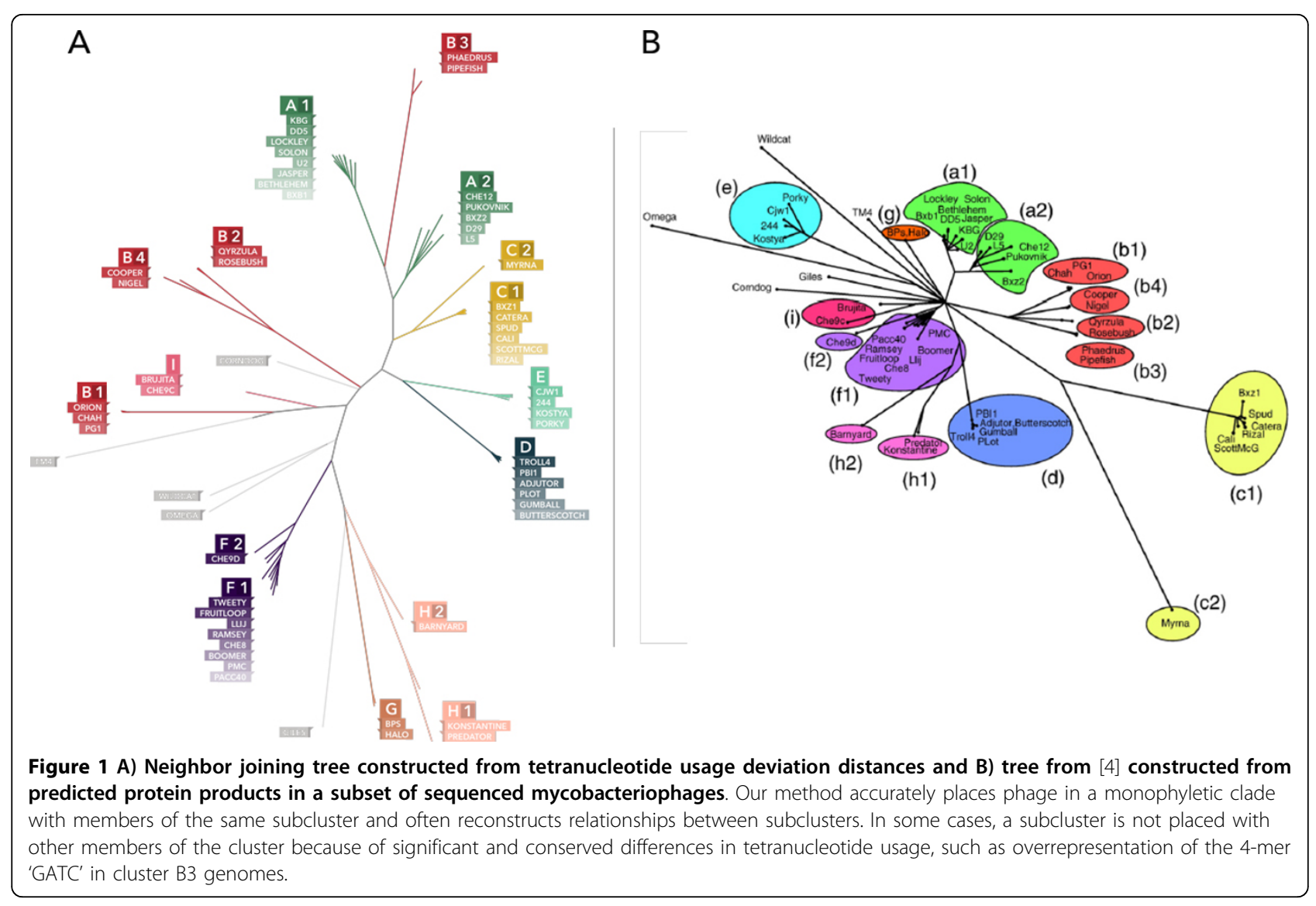

4. Hatfull GF, Jacobs-Sera D, Lawrence JG, Pope WH, Russell DA, Ko C-C, Weber RJ, Patel MC, Germane KL, Edgar RH, Hoyte NN, Bowman CA, Tantoco AT, Paladin EC, Myers MS, Smith AL, Grace MS, Pham TT,

O'Brien MB, Vogelsberger AM, Hryckowian AJ, Wynalek JL, Donis-Keller H, Bogel MW, Peebles CL, Cresawn SG, Hendrix RW: Comparative Genomic Analysis of 60 Mycobacteriophage Genomes: Genome Clustering, Gene Acquisition, and Gene Size. Journal of Molecular Biology 2010, 397:119-143.

doi:10.1186/1471-2105-16-S2-A7

Cite this article as: Siranosian et al.: Tetranucleotide usage in mycobacteriophage genomes: alignment-free methods to cluster phage and infer evolutionary relationships. BMC Bioinformatics 2015 16(Suppl 2): A7.

\section{Submit your next manuscript to BioMed Central} and take full advantage of:

- Convenient online submission

- Thorough peer review

- No space constraints or color figure charges

- Immediate publication on acceptance

- Inclusion in PubMed, CAS, Scopus and Google Scholar

- Research which is freely available for redistribution

Submit your manuscript at www.biomedcentral.com/submit 